\title{
PENGARUH DEBIT TERHADAP UNJUK KERJA ALAT PENUKAR KALOR DAN PENURUNAN SUHU RUANGAN
}

\author{
Mirmanto*, I Made Adi Sayoga, Zulkarnain \\ Teknik Mesin F.T. Universitas Mataram, Jl. Majapahit No.62 Mataram, Nusa Tenggara Barat, \\ 83125, Indonesia \\ *Email : m.mirmanto@unram.ac.id
}

\begin{abstract}
Due to population growth, industry advance and rapid development, fresh and comfortable air may be difficult to get. Conditioning the air to get comfort environment may be a basic demand for people, but the prices of the device and its operation for this purpose are expensive. This research tries to solve this problem but it is just only to know the capability of the heat exchanger to transfer/ absorb heat and is not to cool the room to be below the ambient temperature. The working fluid used was clean water and the heat exchangers employed were parallel and serpentine which were made of copper pipes with a diameter of 1/4 inch and 1/2 inch (for the header). The volumetric flow rates used were $300 \mathrm{ml} /$ minutes, $400 \mathrm{ml} /$ minutes and $500 \mathrm{ml} /$ minutes. While the heat that should be absorbed by the water from the room is $50 \mathrm{~W}$, $100 \mathrm{~W}$ and $150 \mathrm{~W}$. The results show that the effect of volumetric flow rate on heat exchanger performance and room temperature is insignificant. From the pressure drop results, the parallel pipe heat exchanger has lower pressure drops while the serpentine has higher pressure drops.
\end{abstract}

Keywords: volumetric flow rate, heat exchanger, heat exchanger performance, room temperature.

\section{PENDAHULUAN}

Belum lama ini isu pemanasan global dibicarakan di seluruh dunia. Iklim yang tidak menentu, meningkatnya tinggi permukaan air laut, dan meningkatnya suhu di seluruh penjuru bumi merupakan beberapa efek yang timbul dari pemanasan global. Peristiwa ini terjadi karena meningkatnya konsentrasi gasgas rumah kaca seperti karbondioksida dan sebagainya, sehingga radiasi matahari yang seharusnya dipantulkan kembali dari bumi setelah masuk ke bumi, menjadi terperangkap.

Sebagai akibat dari pemanasan global dan letaknya berada di katulistiwa serta pesatnya pertumbuhan penduduk, pemukiman dan industri, maka kenyamanan udara yang sejukpun menurun. Pada kondisi demikianlah, maka perlu adanya upaya untuk mengembalikan ke kondisi yang nyaman dan perlu dicari alternatif lain yang dapat digunakan sebagai penurun tempertur ruangan misalnya adalah menurunkan temperatur ruangan dengan menggunakan air bersih yang dapat diperoleh dari sumur atau PDAM.

Air tersedia melimpah dan harganyapun murah. Terlebih-lebih jika tersedia pompa air dan sumur air, maka air dapat langsung dialirkan dan dimanfaatkan sesuai dengan kebutuhan. Pemanfaatan air untuk penurunan temperatur ruangan cukup mudah dan peralatan yang digunakannyapun sederhana serta perawatannya mudah. Sementra itu, penurunan temperatur ruangan dengan menggunakan air ini masih jarang atau mungkin belum ada dipasaran sehingga alat ini perlu untuk diteliti dan dikembangkan lebih lanjut.

Mintorogo (2003) melakukan suatu penelitian pendinginan ruangan dengan menggunakan air. Pipa-pipa yang berisi air diletakkan di atas atap terbuka untuk melepaskan panas di malam hari secara konduksi, konveksi, dan radiasi. Air yang telah dingin tersebut selanjutnya dimanfaatkan sebagai pendingin ruangan dengan cara mengalirkannya ke pipa-pipa dalam ruangan di atas plafon. Kesimpulan yang dihasilkan dari penelitian Mintrogo (2003) tersebut adalah bahwa pendinginan dengan menggunakan air sangat berpotensi untuk dikembangkan lebih lanjut. Suhu ruangan dapat diturunkan dari $30^{\circ} \mathrm{C}$ ke $25^{\circ} \mathrm{C}$.

Untuk menyerap panas dari ruangan dan membuangnya ke lingkungan diperlukan peralatan yang disebut dengan heat exchanger. Jenis-jenis heat exchanger sangat banyak diantaranya adalah heat exchanger shell and tube, heat exchanger pipa-pipa bersirip, plate heat exchanger dan sebagainya. Berdasarkan aliran dari fluida, heat exchanger dapat dibedakan menjadi heat exchanger aliran searah, aliran berlawanan, aliran menyilang, mixed flow heat exchanger dan unmixed flow heat exchanger, 
direct contact heat exchanger dan sebagainya.

Pada penelitian ini jenis heat exchanger yang dipakai adalah berupa pipa-pipa yang disusun paralel dan serpentin yang dialiri air dingin dan diletakan di bawah tutup kotak prototipe alat penelitian. Pertimbangan pemelihan heat exchanger ini adalah kemudahan dalam pembuatan, murah dan perawatannyapun sederhana. Oleh sebab itu alat penukar kalor ini memungkinkan untuk ditiru oleh masyarakat guna mendinginkan ruangannya. Perbedaan dengan penelitian yang dilakukan oleh Mintorogo (2003) adalah komponen kondensor dan evaporatornya tersusun dalam bentuk heat exchanger koil, sedangkan pada penelitian ini tidak terdapat kondensor sebab air yang digunakan berasal dari sumur dan setelah dilewatkan $\mathrm{HE}$ langsung dibuang ke lingkungan.

\section{FASILITAS DAN METODE PENELITIAN Skema Alat Penelitian}

Skema alat penelitian dapat dilihat pada gambar 1 dan seksi uji dapat dilihat pada gambar 2. Ruangan pada mulanya berada pada suhu lingkungan sekitar $28 \mathrm{~s} / \mathrm{d}$ $30^{\circ} \mathrm{C}$. Kemudian heater di dalam kotak prototipe di hidupkan. Akibat panas dari heater, suhu ruangan naik perlahan-lahan dan akhirnya mencapai suhu tertentu yang disebut dengan suhu kesetimbangan. Pada suhu kesetimbangan ini keadaan ruangan sudah mencapai steadi dan semua suhu dicatat. Kemudian air dingin dari kran dialirkan dan suhunya sekitar $27 \mathrm{~s} / \mathrm{d} 29^{\circ} \mathrm{C}$. Akibat aliran air di dalam heat exchanger ini suhu ruangan kemudian turun kembali dan akhirnya juga mencapai kesetimbangan termal atau steadi. Pada kondisi ini semua suhu, tekanan dan debit air dicatat.

Suhu air, udara di dalam ruangan dan udara di luar ruangan semuanya dicatat dengan menggunakan termokopel tipe $\mathrm{K}$ dengan akurasi $\pm 0,2^{\circ} \mathrm{C}$ hasil kalibrasi. Sedangkan perbedaan tekanan pada sisi inlet dan outlet dicatat diukur dengan menggunakan pressure transducer 26PCCD yang telah dikalibrasi dengan akurasi $\pm 0,2$ $\mathrm{kPa}$. Aliran air diukur dengan menggunakan gelas ukur yang resulosinya $10 \mathrm{ml}$ dan stopwatch dengan resolusi 1/100 detik.

Alat uji/heat exchanger terbuat dari pipa-pipa tembaga dengan diameter $1 / 2$ in untu headernya dan $1 / 4$ in untuk pipa-pipa paralel dan serpentin. Ukuran total ruangan prototipe adalah $50 \mathrm{~cm} \times 50 \mathrm{~cm} \times 50 \mathrm{~cm}$ yang terbuat dari triplek dengan ketebalan $5 \mathrm{~mm}$ yang dikencangkan dengan kayu dan baut.

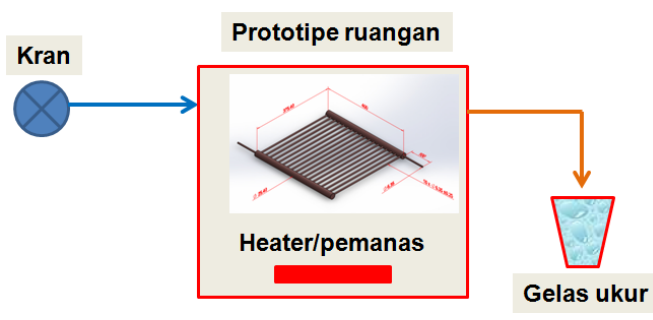

Gambar 1. Skema alat penelitian

Debit aliran yang diuji adalah 300,400 dan $500 \mathrm{ml} /$ menit sedangkan daya heater yang digunakan adalah 50, 100 dan $150 \mathrm{~W}$ (daya apparent) yang diukur dengan menggunakan clamp meter dengan resolusi $1 / 100$ untuk arus maupun tegangan.

\section{Data Reduksi}

Perpindahan panas yang terjadi di dalam ruangan prototipe ada dua macam yaitu perpindahan panas konveksi alamiah, dimana panas dari udara yang bergerak secara alami mengalir masuk ke dalam pipa heat exchanger yang kemudian diserap oleh air yang mengalir di dalam pipa heat exchanger tersebut. Panas yang mengalir dari udara ke dinding pipa heat exchanger dapat diprediksi dengan persamaan (Holman, 1988):

$q=h_{o} A\left(T_{w}-T_{\infty}\right)$

dimana $q$ adalah laju aliran panas dari udara ke dinding pipa (W), $h_{0}$ menyatakan koefisien perpindahan panas konveksi bebas $\left(\mathrm{W} / \mathrm{m}^{2}{ }^{\circ} \mathrm{C}\right)$, $T_{w}$ adalah suhu dinding pipa heat exchanger (diukur pada penelitian ini), dan $T_{\infty}$ menyatakan suhu udara rata-rata di dalam ruangan prototipe pada keadaan steadi dan heat exchanger dialiri air. $A$ menyakan luasan perpindahan panas $\left(\mathrm{m}^{2}\right)$. Sementara $h_{0}$ dapat dicari dengan persamaan (Holman, 1988; Cengel, 1997):

$h_{o}=\frac{\mathrm{Nu} k_{u}}{D_{o}}$

dimana $\mathrm{Nu}$ adalah angka Nusselts, $k_{u}$ menyatakan konduksi termal udara $\left(\mathrm{W} / \mathrm{m}{ }^{\circ} \mathrm{C}\right)$, dan $D_{o}$ adalah diameter luar pipa heat exchanger $(m)$. Nu itu sendiri untuk konveksi bebas dihitung dengan menggunakan persamaan Churchill dan Chu (Holman, 1988): 

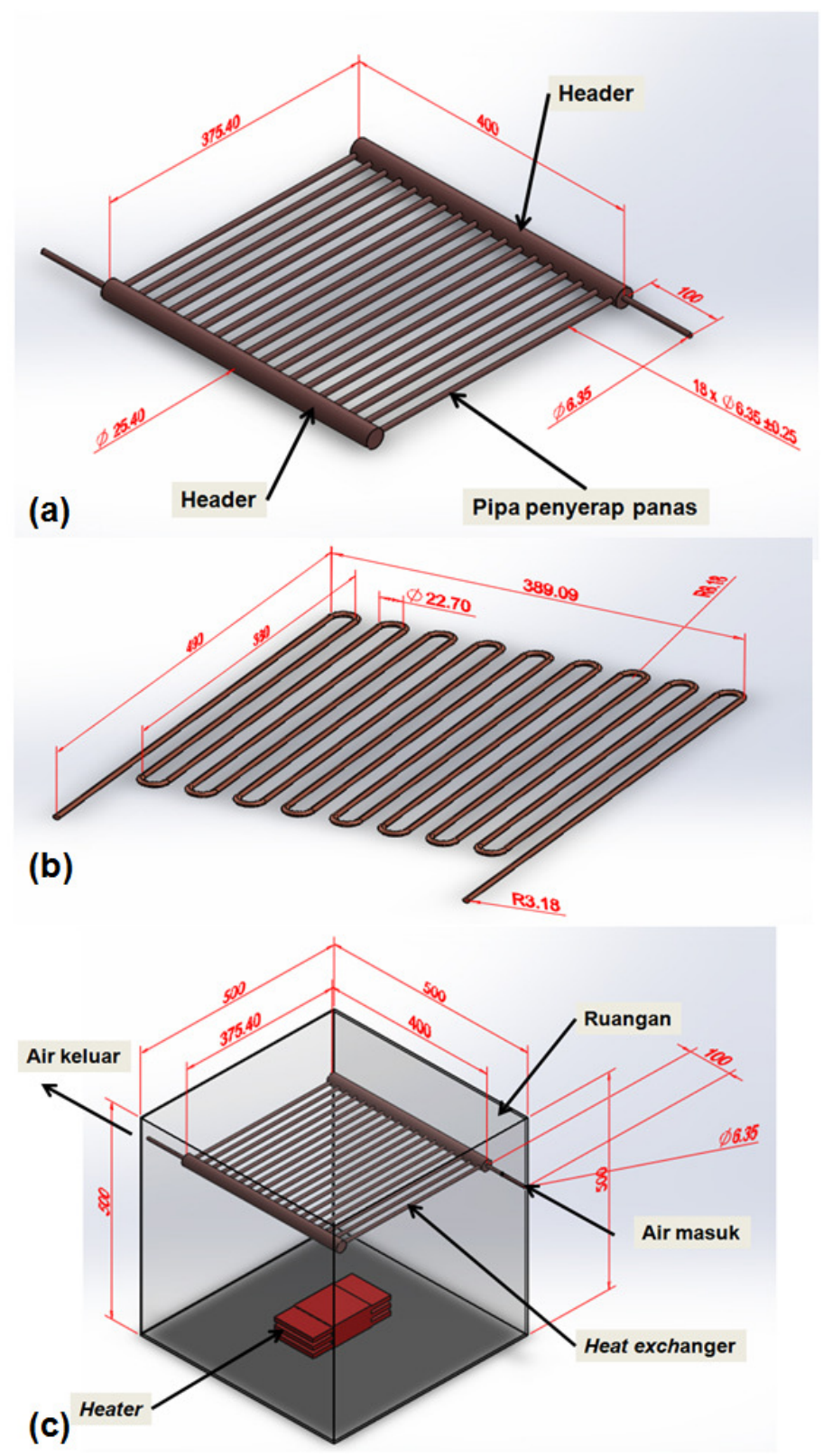

Gambar 2. Heat exchanger/seksi uji (a) pipa paralel, (b) pipa serpentin, (c) prototipe ruangan

$$
\mathrm{Nu}=\left[\begin{array}{l}
0,6+0,387 \\
\left\{\frac{\mathrm{Gr} P r}{\left[1+(0,559 / \mathrm{Pr})^{9 / 16}\right]^{16 / 9}}\right\}^{1 / 6}
\end{array}\right]^{2}
$$

Pr adalah angka Prandtl yang dapat dicari pada tabel sifat-sifat fisis fluida dan Gr adalah angka Grashoft yang dapat diprediksi dengan persamaan (Holman, 1988; Cengel, 1997):

$G r=\frac{g \beta\left(T_{w}-T_{\infty}\right) D_{o}^{2}}{v^{2}}$

dimana $v$ adalah viskositas kinematis udara $\left(\mathrm{m}^{2} / \mathrm{s}\right)$ yang dapat dicari pada tabel sifat-sifat fisis udara. $\beta$ adalah koefisien ekspansi volume dan dapat ditulis sebagai $1 / T$. $T$ merupakan suhu rata-rata dari suhu dinding 
heat exchanger dan suhu udara rata-rata dan harus dalam satuan Kelvin, (Holman, 1988):

$$
T=\left(T_{w}+T_{\infty}\right) / 2
$$

Panas yang diserap oleh air $\left(q_{\text {rem }}\right)$ di dalam pipa bundar dalam heat exchanger dapat diprediksi dengan persamaan (Holman, 1988):

$q_{\text {rem }}=\dot{m} c_{p}\left(T_{o}-T_{i}\right)$

dengan $\dot{m}$ laju aliran massa air $(\mathrm{kg} / \mathrm{s}), c_{p}$ adalah panas jenis air $\left(\mathrm{W} / \mathrm{kg}{ }^{\circ} \mathrm{C}\right), T_{0}$ menyatakan suhu air keluar dan $T_{i}$ adalah suhu air masuk heat exchanger.

Hasil-hasil penelitian yang berkaitan dengan pembandingan akan dilakukan dengan menggunakan uji Anova dan menggunakan error analysis. Hal ini akan ditampilkan pada paper ini sebab hampir seluruh penelitian di Teknik Mesin Unram selalu menggunakan uji Anova. Sedangkan error analysis ditampilkan untuk membantu mahasiswa agar mampu memahami caracara menganalisis ketidak pastian dan dapat pula digunakan untuk membandingkan dua kelompok data yang masing-masing individu data mempunyai error tersendiri. Analysis error ini menggunakan petunjuk pada buku Coleman and Steele (2009). Ketidak pastian pengukuran atau error pada dasarnya dikelompokan menjadi sistematik error dan random error. Sistematik arror dapat diperbaiki misal dengan cara mengkalibrasi alat ukur sedangkan random error tidak dapat diperbaiki tetapi dapat diperkecil dengan cara memperbanyak data pengukuran. Misal mengukur suhu $X$ dilakukan berulang kali dengan menggunakan termokopel, maka ketidak pastian sistematiknya adalah standar deviasi kalibrasi termokopel, tetapi jika tidak dikalibrasi, maka sistematik errornya dapat diperoleh pada spesifikasi termokopel tersebut. Karena pengukuran satu titik dilakukan berkali-kali maka akan timbul standar deviasi dan standar deviasi inilah menjadi salah satu random error. Perlu dicatat bahwa pengukuran berkali-kali dalam penelitian atau pengukuran adalah prosedur yang betul. Jika pengukuran dilakukan hanya satu kali, maka timbulah keraguan nilai kebenaran dari data yang diperoleh. Oleh sebab itu setiap individu memiliki ketidak pastian sendiri-sendiri. Jika ketidak pastian sistematik adalah $B$ dan ketidak pastian random adalah $R$ maka ketidak pastian total dari suhu yang diukur tersebut minimal sama dengan, Coleman and Stelee (2009):

$U_{T}=\sqrt{B^{2}+R^{2}}$

Persamaan untuk propagasi ketidakpastian dapat dilihat pada Coleman and Stelee (2009). Tetapi contoh persamaan akan diberikan di sini. Misal, ketidak pastian dari persamaan (6) dapat diprediksi sebagai berikut, Coleman and Stelee (2009):

$$
U_{q_{r e m}}=\left[\begin{array}{l}
\left(\frac{\partial q_{r e m}}{\partial \dot{m}} U_{\dot{m}}\right)^{2}+ \\
\left(\frac{\partial q_{r e m}}{\partial T_{o}} U_{T_{o}}\right)^{2}+ \\
\left(\frac{\partial q_{r e m}}{\partial T_{i}} U_{T_{i}}\right)^{2}
\end{array}\right]^{0,5}
$$

$U$ menyatakan ketidak pastian atau error, sedangkan ketidak pastian dari panas jenis $c_{p}$ dianggap nol sebab nilai $c_{p}$ diperoleh dari tabel.

\section{HASIL DAN PEMBAHASAN}

Gambar 3 menunjukan perbandingan kalor yang diserap oleh air $\left(q_{\text {rem }}\right)$ pada berbagai debit aliran $300 \mathrm{ml} /$ menit, 400 $\mathrm{ml} /$ menit, dan $500 \mathrm{ml} /$ menit untuk daya $50 \mathrm{~W}$, 100 W dan 150 W. Pada gambar 3 nampak bahwa untuk daya yang sama, panas yang diserap air tidak terpengaruh dengan debit aliran. Hal ini sedikit bertentangan dengan persamaan (6). Pada persamaan (6), jika debit aliran naik maka laju perpindahan panas naik untuk $\left(T_{o^{-}} T_{i}\right)$ konstan. Tetapi kenyataanya adalah tidak, hal ini disebabkan karena jumlah panas yang diserap oleh heat exchanger pada kondisi jenuh/maksimum adalah tetap. Disamping itu, suhu air masuk juga sama, sehingga persamaan (6) dapat dipahami apabila $\dot{m}$ naik maka $\left(T_{o}-T_{i}\right)$ justru turun. Dengan demikian laju perpindahan panasnya tetap selama daya yang diberikan sama/tetap. 


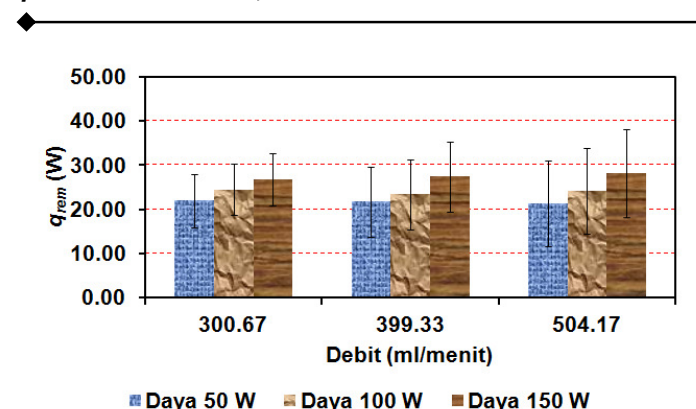

Gambar 3. Pengaruh debit terhadap laju perpindahan panas ke air.

Apabila gambar 3 dianalisis menggunakan uji Anova, maka pengaruh debit tidak siknifikan tetapi pengaruh daya sangat siknifikan. Namun demikian jika pengaruh ke dua variabel tersebut diuji dengan error analysis dengan menampilkan error bar, maka kedua variabel tersebut tidak berpengaruh siknifikan terhadap laju perpindahan panas. Hal ini dibuktikan dengan adanya error bar yang masih saling berkaitan rentang ketidakpastiannya. Jadi pada pembahasan ini memang sengaja disajikan data yang diuji pengaruhnya terhadap variabel tertentu dengan dua metode yaitu metode Anova dan error analysis. Error analysis yang digunakan mengikuti buku Coleman and Steele (2009). Kedua analisis membuktikan bahwa jika setiap individu variabel memiliki ketidakpastian, maka error analysislah yang tepat digunakan dan sebaliknya.

Untuk memperkuat penjelasan yang berkaitan dengan gambar 3 , gambar 4 menyajikan $\left(T_{0^{-}}\right.$ $\left.T_{i}\right)$ terhadap debit aliran untuk berbagai daya. Dari gambar 4 dapat dilihat bahwa pengaruh debit terhadap kenaikan suhu air sangat siknifikan pada daya yang sama dan debit yang berbeda berdasarkan uji Anova. Namun, jika diuji dengan error analisis, pengaruh debit maupun daya tidak siknifikan terhadap $\left(T_{o}-T_{i}\right)$. Pengaruh yang tidak siknifikan ini disebabkan oleh ketidakpastian suhu yang besar. Dengan menggunakan error propagation (Coleman and Steele, 2009), ketidak pastian total dari $q_{\text {rem }}$ menjadi besar. Ketidak pastian dari suhu baik itu suhu sisi masuk ataupun keluar dari air adalah sebesar $\pm 0,2{ }^{\circ} \mathrm{C}$, sehingga error propagation nya adalah $\pm 0,28^{\circ} \mathrm{C}$. Jika yang digunakan patokan adalah $90 \%$ kepercayaan, maka data akan siknifikan pengaruhnya apabila $\Delta T$ yang diukur adalah minimal $2,8^{\circ} \mathrm{C}$. Selama $\Delta T$ kurang dari $2,8^{\circ} \mathrm{C}$, maka pengaruh dari debit dan daya pemanas ruangan tidak siknifikan terhadap $\Delta T$. Akibat ketidak pastian suhu yang besar ini, maka pada gambar 3 , pengaruh debit dan daya terhadap laju perpindahan panas menjadi tidak siknifikan. Namun demikian pada penelitian ini tidak dapat dihasilkan $\Delta T$ yang tinggi sebab perbedaan antara suhu air masuk dan suhu udara sebelum air dialirkan hanyalah berkisar $20-30^{\circ} \mathrm{C}$. Demikian pula perbedaan antara suhu lingkungan dengan suhu ruangan berkisar antara $20-30^{\circ} \mathrm{C}$. Dengan perbedaan suhu ini, panas yang diserap oleh air tidak banyak karena sebagian panas keluar ke lingkungan. Kecilnya panas yang diserap air menimbulkan $\Delta T$ yang kecil.

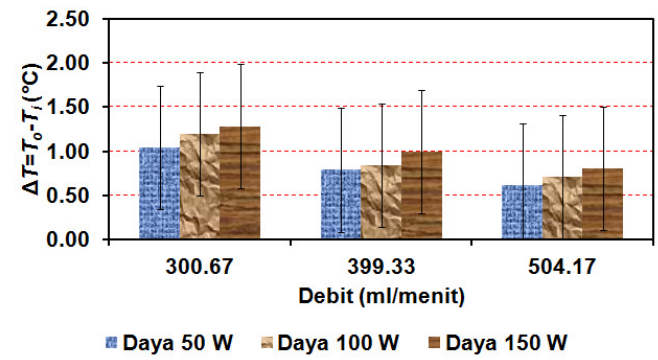

Gambar 4. Pengaruh debit aliran dan daya panas terhadap $\Delta T$.

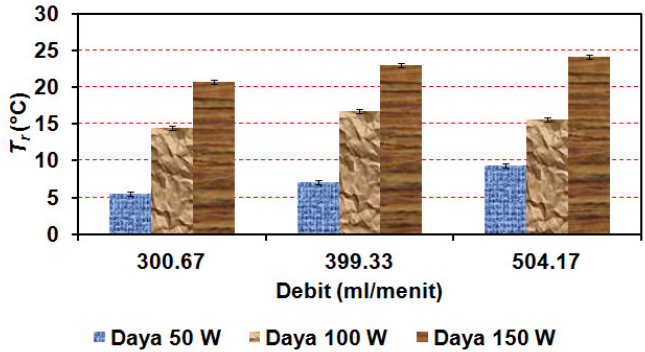

Gambar 5. Pengaruh debit aliran dan daya terhadap penurunan suhu ruangan.

Gambar 3 menunjukan bahwa debit aliran tidak berpengaruh terhadap laju perpindahan panas dari ruangan ke aliran air, tetapi bagaimanakah pengaruh debit aliran dengan penurunan suhu ruangan? Hubungan antara debit aliran dengan penurunan suhu ruangan dapat ditunjukan pada gambar 5 .

Gambar 5 menunjukan adanya pengaruh dari debit aliran atupun daya heater terhadap penurunan atau besarnya suhu yang diturunkan. Pada daya yang sama dengan meningkatnya debit aliran, maka penurunan suhu akan naik. Hal ini dapat diterima, sebab dengan debit yang tinggi, panas yang diserap dari ruangan oleh aliran air juga meningkat. Tetapi dengan adanya gambar 3 dan 4, fenomena ini justru bertentangan. Pada 
gambar 3 tidak ada pengaruh debit aliran terhadap kalor/panas yang diserap oleh aliran air, sedangkan penurunan suhu ruangan dipengaruhi oleh debit aliran. Artinya bahwa perpindahan panas yang terjadi secara alamiah dari udara ke heat exchanger dipengaruhi oleh debit aliran.

Demikian pula dengan daya yang meningkat, suhu yang dapat diturunkan juga naik. Hal ini sebenarnya bertentangan dengan gambar 3 dan 4. Namun demikian hal ini dapat dipahami dengan cara menelusuri kondisi percobaan. Kotak prototipe tidak diisolasi, artinya dengan adanya penambahan daya, suhu di dalam ruangan sebelum air dingin dialirkan akan lebih tinggi dibandingkan dengan suhu ruangan pada daya rendah. Seiring dengan naiknya suhu ruangan, panas yang mengalir ke lingkungan juga meningkat. Meningkatnya panas keluar ruangan ini mempengaruhi/membantu penurunan suhu ruangan, sehingga ketika air dingin dialirkan maka suhu ruangan drop secara siknifikan.

Berdasarkan gambar 6 s/d 8, pengaruh bentuk HE terhadap suhu akhir ruangan siknifikan. Bentuk paralel menghasilkan suhu akhir ruangan yang lebih tinggi dibandingkan dengan bentuk serpentin. Trend ini sama untuk semua daya yang diberikan, suhu ruangan dengan $\mathrm{HE}$ paralel lebih tinggi.

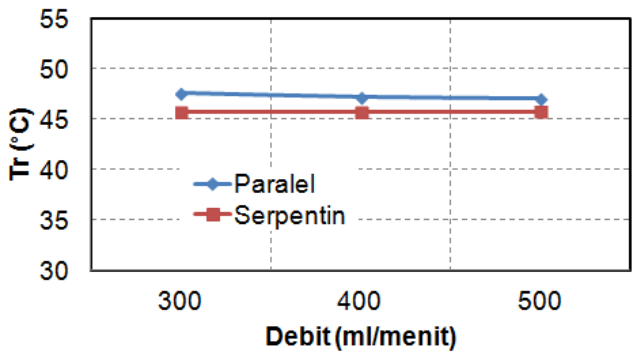

Gambar 6. Hubungan $\operatorname{Tr}$ dengan debit debit 300, 400 dan $500 \mathrm{~cm}^{3} /$ menit pada pipa parallel dan serpentin dengan daya $50 \mathrm{~W}$.

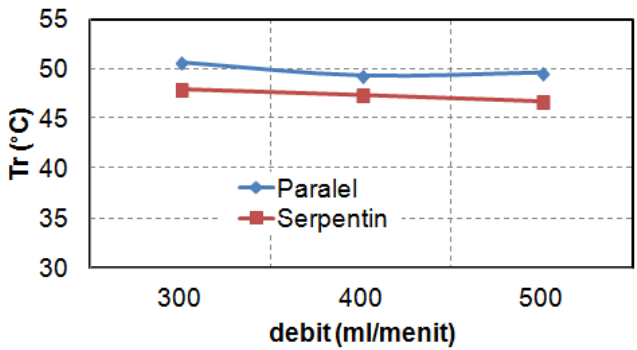

Gambar 7. Hubungan $\operatorname{Tr}$ dengan debit debit 300, 400 dan $500 \mathrm{~cm}^{3} /$ menit pada pipa parallel dan serpentin dengan daya $100 \mathrm{~W}$.
Burlian dan Khoirullah (2014) semakin tebal isolator semakin kecil kerugian panas kelingkungan. Demikian pula, dengan adanya susunan seri dan peralael, Tarigan (2003) menyatakan bahwa dengan hadirnya buffle atau hambatan maka perpindahan kalornya lebih tinggi. Ini sesuai dengan yang bentuk serpentin dimana terdapat banyak hambatan karena belokan-belokan.

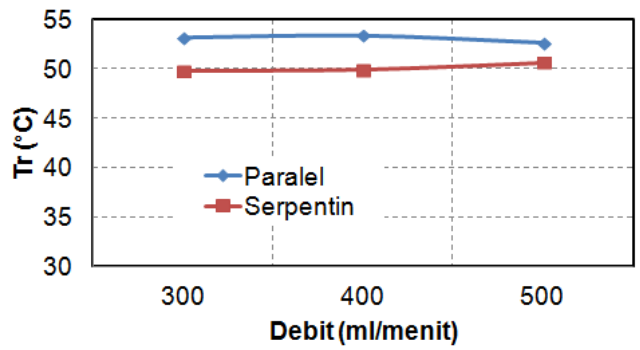

Gambar 8. Hubungan $T r$ dengan debit debit 300, 400 dan $500 \mathrm{~cm}^{3} /$ menit pada pipa parallel dan serpentin dengan daya $150 \mathrm{~W}$.

Kerugian tekanan yang dihasilkan oleh dua bentuk pipa yang berbeda pada debit yang berbeda dapat dilihat pada pada gambar 9 berikut:

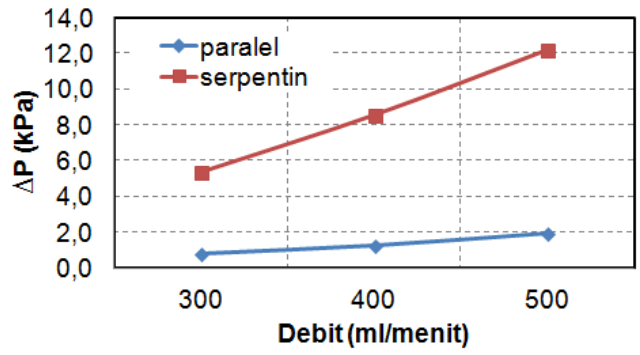

Gambar 9. Hubungan $\Delta P$ dengan debit debit 300,400 dan $500 \mathrm{~cm}^{3} /$ menit pada pipa parallel dan serpentin.

Dari gambar 9 di atas, terlihat kerugian tekanan yang terjadi semakin naik seiring dengan bertambahnya debit air. Hal ini terjadi karena dipengaruhi oleh kecepatan aliran air (V), semakin besar debit yang dialirkan maka semakin tinggi kecepatan aliran air, lihatlah persamaan pressure drop, persamaan (9), Stocher and Jones (1989).

$\Delta p=\frac{f L}{D} \rho \frac{V^{2}}{2}$

Untuk dua bentuk pipa yang berbeda, pipa parallel memiliki kerugian tekanan yang lebih kecil dibandingkan dengan pipa serpentin untuk daya dan debit yang sama. 
HE yang paralel tersusun atas pipa-pipa yang pendek dan kecepatan aliran pada masingmasing pipa sangat rendah sedangkan pipa serpentin jauh lebih panjang dan aliran fluidanya cepat sehingga berdasarkan persamaan pressure drop pipa serpentin menghasilkan pressure drop yang lebih besar.

\section{KESIMPULAN}

Dari hasil pembahasan dapat diambil beberapa kesimpulan sebagai berikut:

1. Pengaruh bentuk HE pipa paralel dan serpentin terhadap kenaikan suhu ruangan siknifikan.

2. Penurunan temperatur ruangan $(T r)$ oleh debit aliran tidak signifikan.

3. Suhu air keluar $(\Delta T)$ tidak dipengaruhi oleh bentuk HE tetapi dipengaruhi oleh debit aliran.

4. Kerugian tekanan pada pipa parallel lebih kecil dari pada pipa serpentin. Oleh sebab itu bentuk HE yang baik adalah HE pipa paralel.

\section{DAFTAR SIMBOL}

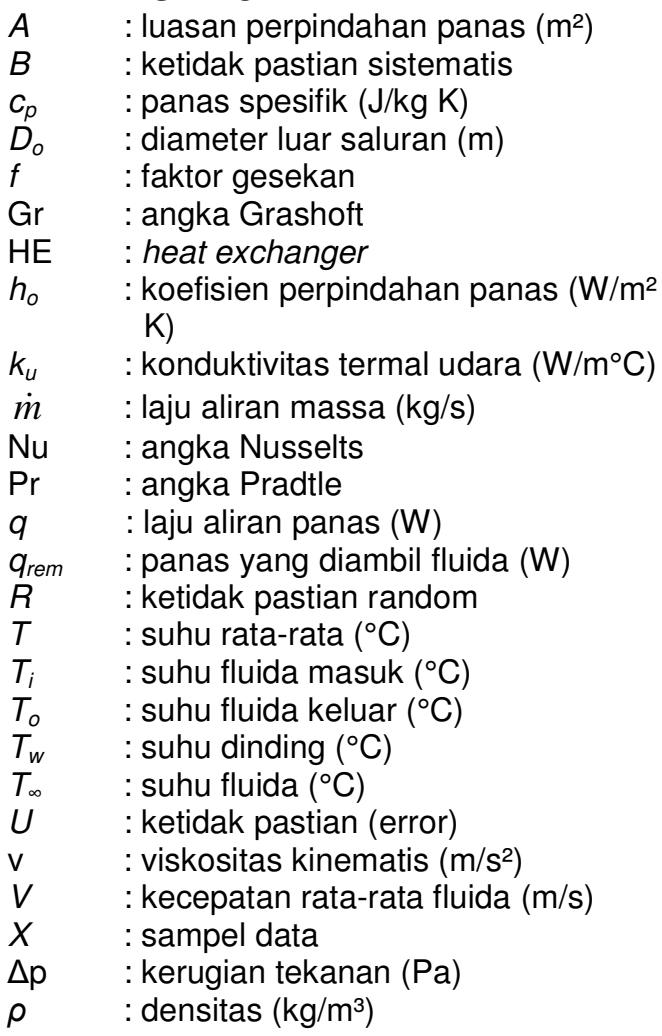

\section{DAFTAR PUSTAKA}

Burlian F., Khoirullah M. I., 2014, Pengaruh variasi ketebalan isolator terhadap laju kalor dan penurunan temperatur pada Permukaan Dinding Tungku
Biomassa, Jurusan Teknik Mesin, Universitas Sriwijaya.

Cengel Y.A., 1997, Introduction to Thermodynamics and Heat Transfer, Mc. Graw Hill, Inc., New york.

Holman J.P.,1988, Perpindahan Kalor, Erlangga, Jakarta.

Mintorogo D.S.,2003, Strategy water based condenser, Jurnal Teknik Arsitektur, vol. 31, No. 2, 141-151.

Stocher W.F., Jones J.W, 1989, Refrigeration and Air Conditioning, Mc. Graw Hill International Edition.

Tarigan B.V., 2003, Pengaruh penggunaan baffles dan material baffles terhadap unjuk kerja kolektor surya plat datar dengan bentuk bertingkat, Jurusan Teknik Mesin, Universitas mataram. 